\title{
Nowa strategia leczenia częściowej głuchoty - 10 lat doświadczeń
}

\section{Ten years experience with a new strategy of partial deafness treatment}

\author{
Henryk Skarżyński ${ }^{1,2}$ \\ ${ }^{1}$ Instytut Fizjologii i Patologii Słuchu, ul. Zgrupowania AK „Kampinos” 1, 01-943 Warszawa \\ ${ }^{2}$ Światowe Centrum Słuchu, ul. Mokra 17, Kajetany, 05-830 Nadarzyn
}

Adres autora: Henryk Skarżyński, Instytut Fizjologii i Patologii Słuchu, ul. Zgrupowania AK „Kampinos” 1, 01-943 Warszawa

\section{Streszczenie}

Leczenie częściowej głuchoty stanowiło wielkie wyzwanie w aspekcie zachowania słuchu przedoperacyjnego i uzupełnienia możliwości słyszenia za pośrednictwem implantu. W szczególności odnosiło się to do sytuacji gdy słuch w zakresie niskich częstotliwości był w normie lub w pełni wydolny i niezbędne było tylko jego elektryczne dopełnienie w zakresie średnich i wysokich częstotliwości. Przeprowadzona przed 10 laty pierwsza operacja elektrycznego dopełnienia do istniejącego, normalnego słuchu pokazała nowy kierunek leczenia różnych częściowych, coraz częściej spotykanych uszkodzeń słuchu. Długi okres obserwacji oraz zebranie bardzo dużego materiału obejmującego ponad 1200 zoperowanych uszu pozwolił na przedstawienie nowej strategii leczenia częściowej głuchoty. Przeprowadzona przed 10 laty pierwsza operacja elektrycznego dopełnienia istniejącego słuchu u osoby dorosłej a w 2004 r. u pierwszego dziecka z takim samym słuchem była poprzedzona 3-letnimi badaniami nad zachowaniem istniejących niewielkich resztek słuchowych u dzieci i dorosłych, które były wzmacniane konwencjonalnymi aparatami słuchowymi i stymulowane elektrycznie za pośrednictwem implantów. Wyniki tych prac, przedstawione w 2000 r. podczas ESPCI w Antwerpii i w 2000 r. podczas Kongresu EUFOS w Berlinie, wskazywały na potrzebę rozszerzenia pierwszych ostrożnych wskazań do stosowania implantów ślimakowych w przypadkach zachowanych w różnym stopniu resztek słuchowych $\mathrm{w}$ zakresie niskich częstotliwości. Udokumentowanie dużej grupy zoperowanych uszu z częściową głuchotą podczas 10 lat jej upowszechniania w świecie, potwierdzało zasadność przyjętych wskazań oraz założeń chirurgicznych. W szczególności dotyczą one opracowania własnej strategii operacyjnej opartej na wykonaniu 6 zasadniczych kroków, dojściu do schodów bębenka przez okienko okrągłe i wykorzystaniu niezwykle delikatnych elektrod o długości aktywnej od 20 do $28 \mathrm{~mm}$. Podsumowując, ta nowa strategia pozwoliła na opublikowanie w 2010 r. nowego, kompleksowego podejścia do zachowania istniejącego $\mathrm{w}$ różnym stopniu przedoperacyjnego słuchu w coraz większym paśmie niskich częstotliwości i do zachowaniu struktury ślimaka. Pozwoliło to również na zaproponowanie nowej klasyfikacji częściowej głuchoty dla opracowywania wyników homogennych grup pacjentów. Uzupełnieniem działań chirurgicznych był wpływ autora koncepcji na wytworzenie nowych, o różnej długości, niezwykle delikatnych elektrod implantów ślimakowych. Całość podjętych działań zaowocowała rozszerzeniem wskazań do leczenia różnych postaci częściowej głuchoty przy pomocy implantów ślimakowych.

Słowa kluczowe: leczenie częściowej głuchoty • zachowanie słuchu • stymulacja elektryczna i akustyczna • implanty ślimakowe • klasyfikacja głuchoty • Round Window Approach • metoda chirurgiczna

\begin{abstract}
What is now known as partial deafness treatment (PDT) began as a great challenge: insert a cochlear implant and preserve residual preoperative hearing. PDT addresses the situation where patients have low frequency hearing which is not badly affected, or is even fully functional, and it is necessary to complement it electrically in the medium and high frequency ranges. The first surgery in which existing normal hearing was electrically complemented, performed 10 years ago, has opened up a new direction in the treatment of other (more frequent) partial hearing impairments. The long term observation of more than 1512 ears has allowed us to refine a new strategy of PDT.
\end{abstract}

The first surgery to electrically complement the existing hearing of an adult was performed in 2002, and led in 2004 to the same treatment in a child. It was preceded with 3 years of research on how to enhance the low-frequency residual hearing of patients by amplifying it with conventional hearing aids while supplying high frequencies with an electrically stimulated implant. Results of these studies, presented in 2000 at international conferences, demonstrated the potential for widening the 
first, cautious indications for the use of cochlear implants to situations where there are various levels of residual low-frequency hearing. Experience with 1512 cases of partial deafness surgery have proven its general validity and have refined the surgical guidelines. The surgical strategy is based on 6 main steps involving an approach to scala tympani through the round window, and use of electrodes with an active length of 20 to $28 \mathrm{~mm}$.

Key words: partial deafness treatment $\bullet$ hearing preservation $\bullet$ electric and acoustic stimulation $\bullet$ cochlear implants $\bullet$ classification of deafness $\bullet$ round window approach $\bullet$ surgical technique

\section{Wstęp}

Uzyskiwane coraz lepsze rezultaty leczenia głębokiego niedosłuchu i całkowitej głuchoty w szczególności u coraz młodszych dzieci zachęcały naukowców do stałego rozszerzania wskazań do efektywnego wykorzystania metody leczenia przy pomocy implantów ślimakowych. Badania te prowadzone były niezależnie w Europie [1], w USA [2], w Australii [3]. Dotyczyły one zwykle stymulacji elektrycznej za pośrednictwem implantu na jedno ucho i aparatu słuchowego na drugie, rzadziej na jednostronną stymulację akustyczną i elektryczną. Przedstawiona przez nasz zespół podczas V Konferencji ESPCI w Antwerpii [4] pierwsza grupa wyników u 67 dzieci z zachowanymi niewielkimi resztkami słuchowymi stymulowanymi przez aparat słuchowy oraz stymulacja elektryczna za pośrednictwem implantu ślimakowego w tym samym uchu pokazała, że ten kierunek jest zasadny i wymaga dalszego rozwijania. W tym samym roku, podczas Kongresu EUFOS w Berlinie, zaprezentowaliśmy wyniki zachowania resztek słuchowych u pierwszej grupy pacjentów dorosłych [5]. Prowadzona przez 2-3 lata obserwacja dotycząca zachowania niewielkich resztek słuchowych wykazała, że zasadne jest rozszerzenie wskazań do stosowania implantów ślimakowych jako elektrycznego dopełnienia dobrego lub normalnego słuchu na niskich częstotliwościach do poziomu $500 \mathrm{~Hz}$. Elektryczne dopełnienie zastosowano po raz pierwszy u pacjenta dorosłego w 2002 roku [6], a u pierwszego dziecka w 2004 r [7]. Procedura operacyjna została zaproponowana przez Skarżyńskiego, jako strategia 6 kroków uwzględniających dojście do schodów bębenka przez okienko okrągłe jako najbardziej fizjologiczną drogę wprowadzenia elektrody do ucha wewnętrznego [8]. Stała obserwacja coraz większej grupy pacjentów, która liczyła setki, a następnie przekroczyła 1 tysiąc i 1,5 tysiąca wskazywała na pełną zasadność rozwijania tego kierunku. Potwierdzeniem były liczne kolejne doniesienia i prezentacja materiału na wszystkich kontynentalnych konferencjach i kongresach poświęconych implantom słuchowym, audiologii i otologii w ostatnich latach $[8,9]$. Celem było systematyczne pokazywanie nowych grup pacjentów, dłuższego czasu obserwacji, zachowania słuchu przedoperacyjnego w kolejnych latach oraz pokazania nowych technologii elektrod w implantach ślimakowych $[10,11]$. W 2009 r., podczas europejskiej konferencji - IX ESPCI w Warszawie, mogliśmy pokazać nową koncepcję uwzględniającą różny przedoperacyjny słuchu w zakresie niskich częstotliwości [9]. W roku 2010 została opublikowana [8] najnowsza kompleksowa koncepcja pozwalająca pokazać różnice $\mathrm{w}$ podejściu do różnych grup pacjentów z częściową głuchotą (Rycina 1).

Wszystkie zabiegi operacyjne z użyciem implantu ślimakowego zostały przeprowadzone wg metody „6 kroków”
Skarżyńskiego z zachowaniem istniejącej, nienaruszonej struktury ucha wewnętrznego [8]. Rozwój atraumatycznej metody chirurgicznej pozwolił na rozszerzenie wskazań do zastosowania implantów ślimakowych u coraz większej grupy pacjentów oraz przyczynił się do powstawania przełomowych technologii i delikatnych elektrod o różnej długości [10]. W jednej z ostatnich faz rozwojowych "procedury 6 kroków Skarżyńskiego" zastosowano ograniczoną stymulację elektryczną przy pomocy elektrody od 20 do $25 \mathrm{~mm}$ [11]. W ostatnim czasie zastosowano insercję do $28 \mathrm{~mm}$ w głąb schodków bęben$\mathrm{ka}, \mathrm{z}$ zachowaniem istniejącego słuchu na poziomie 250 $\mathrm{Hz}$, który został skutecznie wzmocniony elektro-akustycznie poprzez zastosowanie aparatu słuchowego i implantu ślimakowego [12]. Ostatecznie, pierwsza klasyfikacja leczenia częściowej głuchoty (PDT) została zaproponowana przez prof. Henryka Skarżyńskiego [8]. Jest to model najwyższej wagi w ocenie pooperacyjnych wyników $\mathrm{w}$ heterogenicznych grupach pacjentów $\mathrm{z}$ różnym poziomem przedoperacyjnego zachowanego słuchu. Wyniki uzyskiwane u różnych pacjentów, przez autorów wykorzystujących różne metody oceny, mogą dostarczyć cenny materiał dla dalszego rozwoju kryteriów selekcji do PDT i pomóc ustanowić ją powszechną procedurą interwencyjną. Wszystkie te postępy przyniosły rozwój i upowszechnienie zastosowania nowych technologii w opiece pooperacyjnej (takich jak sieci telemedyczne) oraz w zakresie innych usług zdrowotnych. Niezwykle dobry odbiór rezultatów leczenia częściowej głuchoty przez środowisko pacjentów i ich rodzin miał wpływ na organizację i inwestycje w nowe zaplecze medyczne, czego przykładem jest Światowe Centrum Słuchu.

\section{Materiał}

W ciągu 10 lat metodę leczenia PDT zastosowano w 1512 uszach u dzieci i dorosłych w wieku od 9 miesięcy do 84 lat. W tej grupie dzieci i młodzież do 18 r.ż. stanowili grupę liczącą 405 osób (26,8\%), a osób dorosłych było 1107 $(73,2 \%)$. Przedoperacyjny słuch był ustalany na podstawie badań audiometrycznych u dzieci powyżej 5 roku życia i dorosłych. U dzieci mniejszych podstawą do oceny przedoperacyjnego progu słyszenia było badanie ABR na częstotliwości $0,5 \mathrm{KHz}, 1 \mathrm{KHz}, 2 \mathrm{KHz}$ i $4 \mathrm{KHz}$. Należy podkreślić, że najistotniejszą grupą byli pacjenci z normalnym lub w pełni socjalnie wydolnym słuchem do poziomu $1500 \mathrm{~Hz}$ - PDT-EC. Jako grupa wymagająca jedynie elektrycznego dopełnienia istniejącego słuchu, stanowili oni największe wyzwanie dla operatora, ale jednocześnie byli grupą, która była predysponowana do uzyskiwania najlepszych i najszybszych efektów w pooperacyjnej rehabilitacji. Druga grupa - PDT-EAS, dedykowana do łączonej stymulacji elektro-akustycznej, była do tej pory najliczniejsza. Zapewne wynikało z faktu, że ci pacjenci byli najbardziej zdeterminowani poddać się operacji wszczepienia 


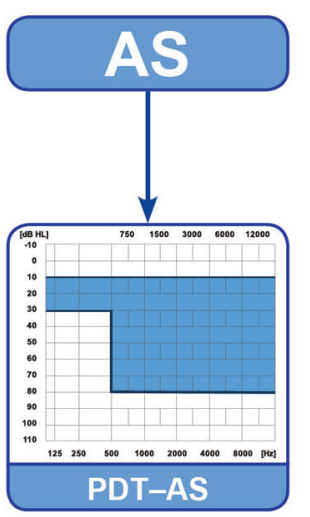

A

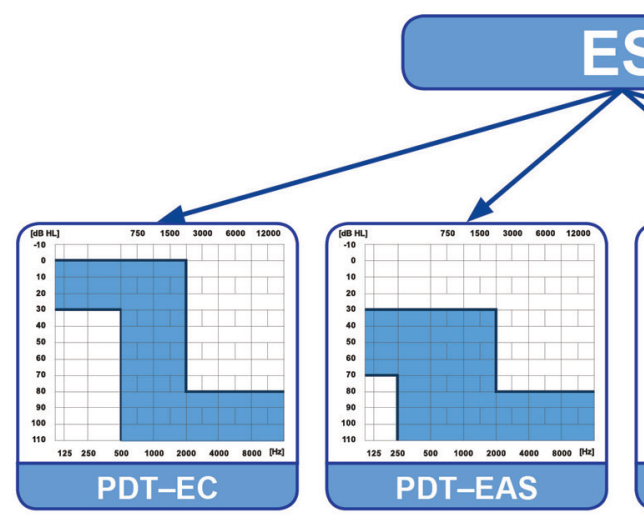

B
C

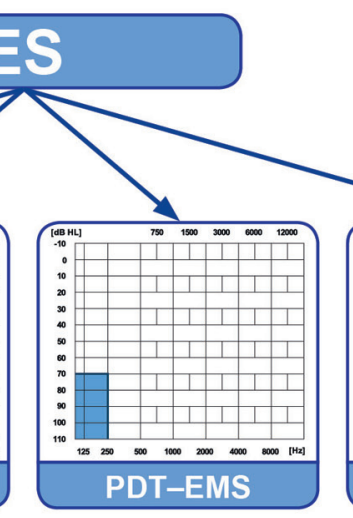

D

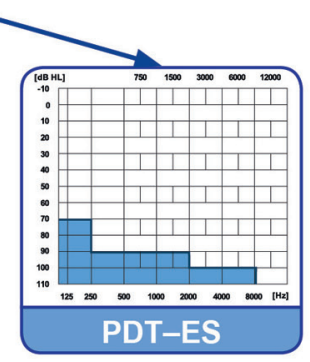

E

Rycina 1. Najnowsza koncepcja wykazania zakresów akustycznej (AS) i elektrycznej (ES) stymulacji w leczeniu częściowej głuchoty: (A) Wzmocnienie słuchu akustycznego poprzez zastosowanie aparatów słuchowych i implantów ucha środkowego (PDT-AS). (B) Elektryczne dopełnienie dobrego słuchu istniejącego w niskich częstotliwościach (PFT-EC). (C) Akustyczne wzmocnienie aparatem słuchowym resztek słuchowych zachowanych w niskich częstotliwościach oraz elektryczna stymulacja innych części tego samego ucha (PDT-EAS). (D) Zmodyfikowana elektryczna stymulacja w przypadkach, w których przedoperacyjny słuch został utracony bez możliwości ponownej operacji (PDT-EMS). (E) Elektryczna stymulacja tylko w przypadkach, w których zachowany słuch na różnych częstotliwościach nie jest czynnościowy (PDT-ES)

Tabela 1. Metoda operacyjna „6. kroków” Skarżyńskiego.

\begin{tabular}{cl}
\hline STEP 1 & Konserwatywna attykoantroidotomia \\
\hline STEP 2 & Tympanotomia tylna w celu umożliwienia wizualizacji niszy okienka okrągłego \\
\hline STEP 3 & Punkcja i nacięcie błony okienka okrągłego \\
\hline STEP 4 & $\begin{array}{l}\text { Wprowadzenie elektrody pod odpowiednim kątem do schodów bębenka przez okienko okrągłe } \\
\text { (częściowe wprowadzenie elektrody) }\end{array}$ \\
\hline STEP 5 & $\begin{array}{l}\text { Uszczelnienie elektrody w okienku okrągłym i umocowanie klejem i tkanką do ściany kostnej w obrębie } \\
\text { wyrostka sutkowatego (membrana musi pozostać częściowo nieodkryta by zachowała mobilność) }\end{array}$ \\
\hline STEP 6 & Umocowanie części wewnętrznej implantu w loży kostnej łuski kości skroniowej \\
\hline
\end{tabular}

implantu. Trzecia grupa - PDT-EMS, była najmniej liczna i stanowiła 3 dzieci oraz 26 osób dorosłych co stanowi 2,57\% całej zoperowanej populacji 1512 uszu. W grupie 36 osób dorosłych, w której doszło w ciągu 6 miesięcy do istotnej utraty słuchu przedoperacyjnego u 27 osób (1,78\% całej zoperowanej populacji), zaobserwowano obustronne pogorszenie słuchu - czyli nie tylko w uchu zoperowanym, a u 9 osób dorosłych (0,59\%) jednostronne - tylko w uchu operowanym. Należy to wiązać z faktem wykonania zabiegu operacyjnego. Wśród dzieci istotne pogorszenie słuchu odnotowano jedynie w 3 uszach. Stanowi to $0,19 \%$ całej zoperowanej populacji i 0,74\% populacji dziecięcej. Co jest znamienne, pogorszenie słuchu w tej grupie dzieci, w okresie 3 miesięcy po operacji, zaobserwowano jedynie w uchu operowanym i nie zaobserwowano obustronnego pogorszenia słuchu. W efekcie, wynik zachowania słuchu przedoperacyjnego utrzymany został u $100 \%$ zoperowanych dzieci, przez 6 lat.

\section{Metoda}

Wszystkie zaprezentowane w tym opracowaniu procedury chirurgiczne dotyczyły dojście do schodów bębenka było przez okienko okrągłe. W 1507 uszach (99,66\%) dojście do niszy okienka nastąpiło poprzez tympanotomię tylną, a w 5 przypadkach $(0,33 \%)$ z dojścia podwójnego przez tympanotomię tylną i przez przewód słuchowy zewnętrzny. W celu prawidłowego wyeksponowania niszy okienka okrągłego konieczna była dodatkowa procedura i elektroda została wprowadzona poprzez wcześniej wykonaną tympanotomię tylną. W każdym zatem uchu możliwe było delikatne wprowadzenie elektrody do schodów bębenka przez naciętą błonę okienka okrągłego i uzyskanie o wymaganej głębokości umieszczenia elektrody. Cała procedura operacyjna była przeprowadzona zgodnie ze metoda operacyjną „6. kroków” Skarżyńskiego (Tabela 1).

Pierwszym krokiem jest wykonanie konserwatywnej antromastoidektomii, czyli wystarczającego dla potrzeb wprowadzenia elektrody otwarcia jamy wyrostka. Czynnością poprzedzającą otwarcie wyrostka, szczególnie u dzieci, jest zdjęcie przy pomocy dłuta fragmentu warstwy korowej, w taki sposób by po wszczepieniu części wewnętrznej implantu przy pomocy tego fragmentu całkowicie odizolować jamę wyrostka od przestrzeni podskórnej, w której była umocowana część wewnętrzna implantu (Rycina 2).

Drugi krok polega się z wykonaniem tympanotomii tylnej (Rycina 3). Dostęp powinien być na tyle szeroki, by chirurg był w stanie śledzić wzrokiem wprowadzanie elektrody do 


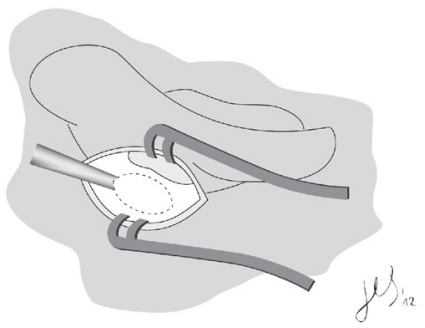

A

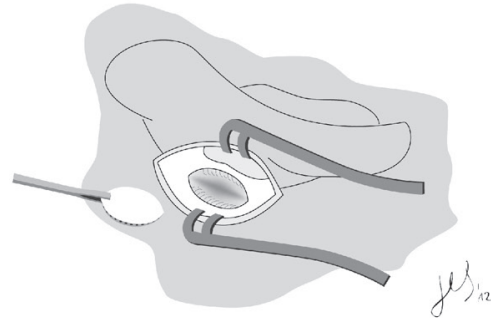

B

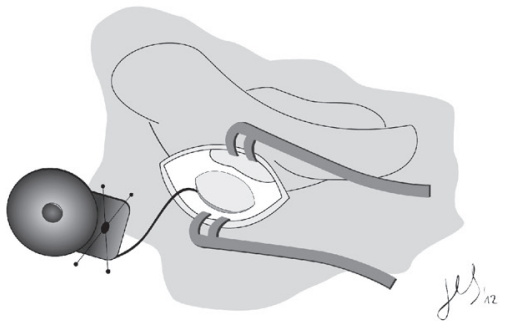

C

Rycina 2. Schemat wyznaczenia obszaru do pobrania wióra kostnego (A), usunięcie przy pomocy dłuta części warstwy korowej wyrostka (B), zamknięcie pobranym wiórem kostnym jamy wyrostka sutkowatego (C)

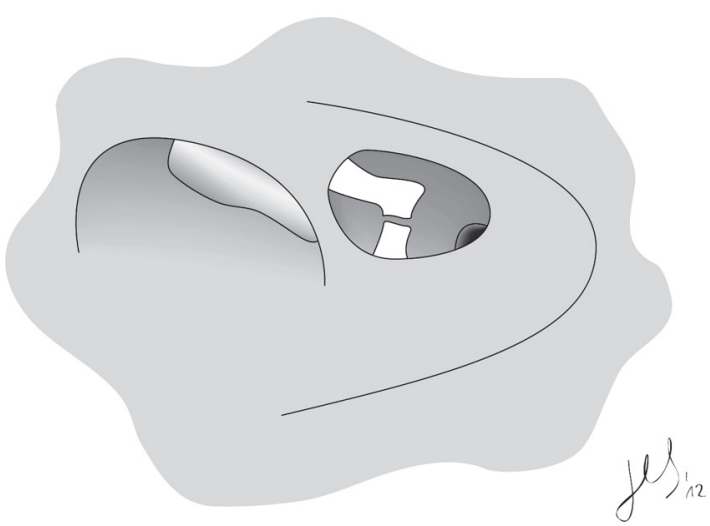

Rycina 3. Tympanotomia tylna z uwidocznioną niszą okienka okrągłego

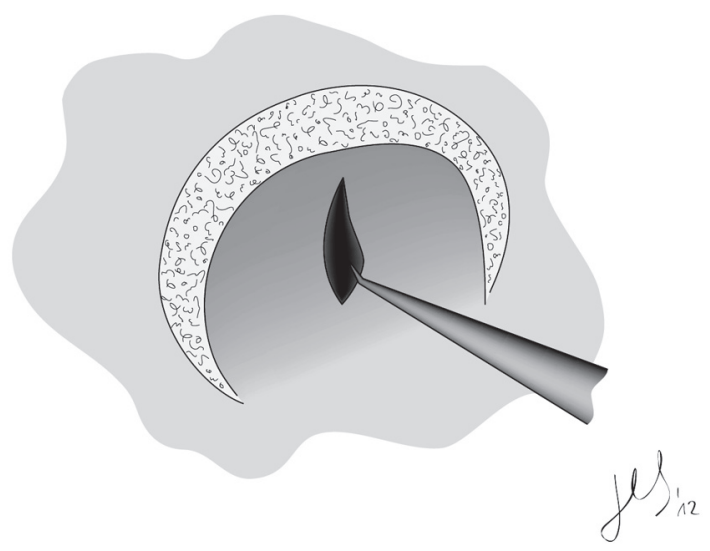

Rycina 4. Trzeci krok procedury chirurgicznej leczenia PDT nakłucie i nacięcie błony okienka okrągłego

niszy okienka okrągłego. Dla potrzeb dobrego uwidocznienia błony okienka, w części przypadków należy znieść wargę boczną, a w niektórych przypadkach wykonuje się dojście podwójne przez przewód słuchowy zewnętrzny.

Trzeci krok polega na delikatnym nacięciu błony okienka okrągłego w celu przygotowania drogi wejścia elektrody do schodów bębenka (Rycina 4).

Następną najważniejszą czynnością jest wykonanie kroku czwartego, w ramach którego wprowadza się elektrodę pod katem zbliżonym do prostego w stosunku do powierzchni błony okienka okrągłego (Rycina 5). Takie ustawienie elektrody przed wprowadzeniem do schodów bębenka autor

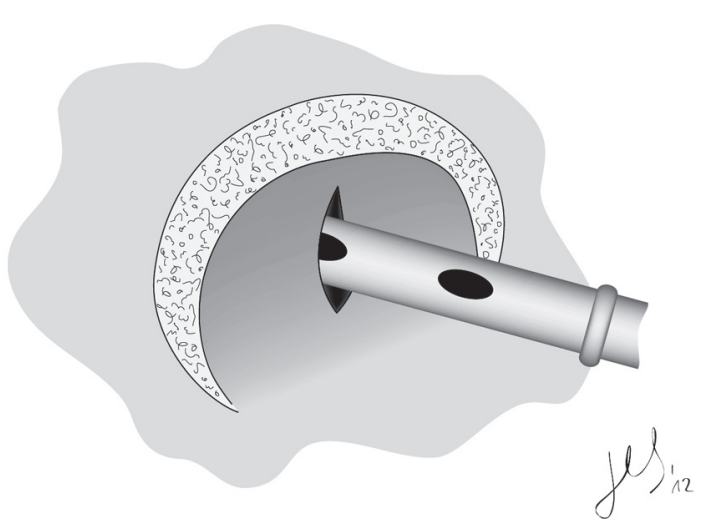

Rycina 5. Czwarty krok procedury - insercja elektrody do schodów bębenka

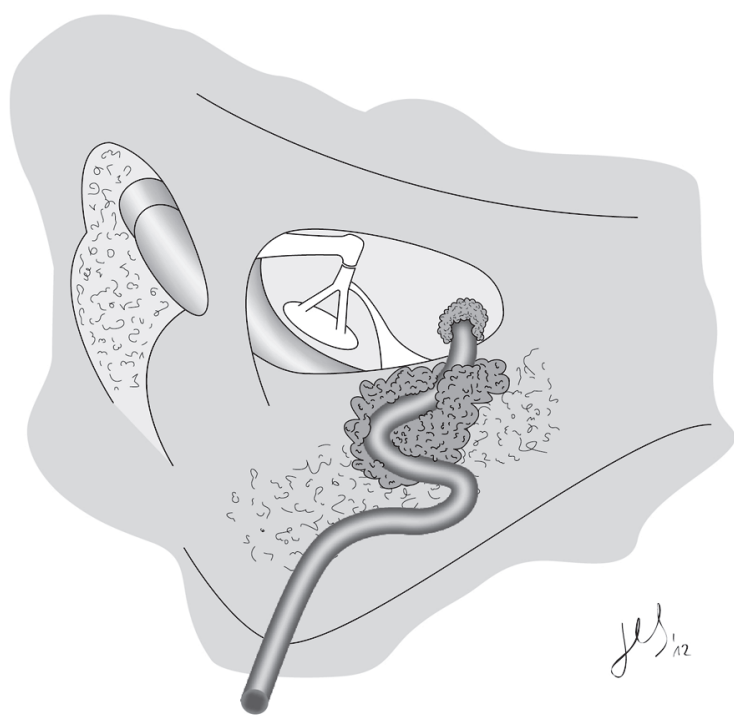

Rycina 6. Piąty krok procedury chirurgicznej - uszczelnianie i umocowanie elektrody

procedury uważa za najmniej traumatyczne. Na początku wprowadzania elektrody do schodów bębenka, zalecane jest trzymanie jej w palcach dla lepszego wyczucia oporów. Jedynie końcowe czynności wprowadzania elektrody do schodów bębenka są wykonywane przy pomocy kleszczyków.

Piąty krok polega na uszczelnieniu wejścia elektrody do schodów bębenka oraz jej umocowaniu w obrębie tympanotomii tylnej przy pomocy fragmentu powięzi i kleju 


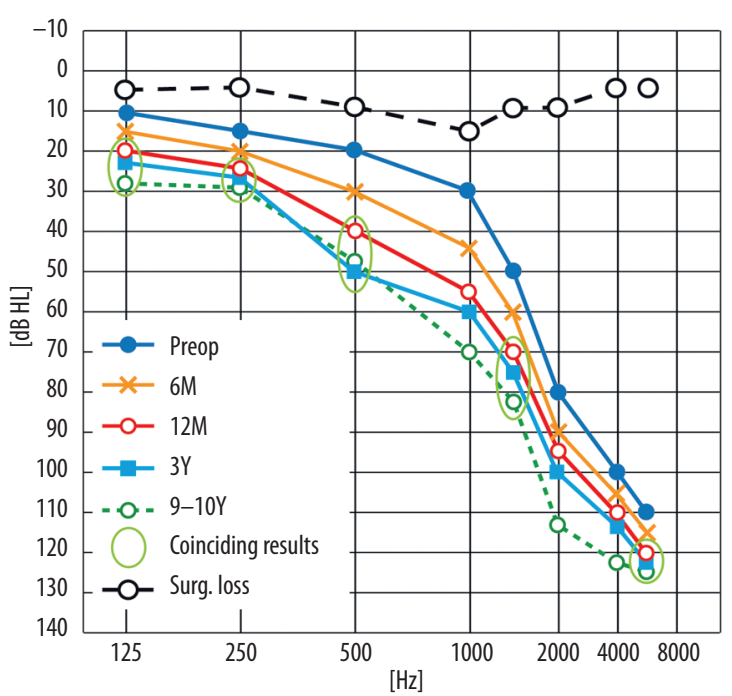

Rycina 7. Przedoperacyjne progi i po operacyjne wyniki zachowania słuchu w grupie PDT-EC, gromadzone w ciągu 10 lat $(n=31)$

tkankowego (Rycina 6). Pozostała część elektrody jest zwijana w jamie wyrostka. Wejście do wyrostka było zamykane fragmentem spongostanu, na którym przy pomocy kleju tkankowego mocuje się pobrany podczas pierwszego kroku fragment warstwy korowej wyrostka.

Ostatni, 6 krok czynności chirurgicznych polega na przygotowaniu loży dla części wewnętrznej implantu i jej mocowaniu przy pomocy cementu jonometrycznego lub niewchłanianych szwów co uwidoczniono na Rycinie 2C. $\mathrm{W}$ fazie końcowej następuje zeszycie ran pooperacyjnych za uchem. Zakończenie zabiegu operacyjnego polega na założeniu u wszystkich pacjentów dorosłych i większości dzieci na okres 2 dni drenażu ssącego.

Dwa rodzaje systemu implantu ślimakowego zostały wykorzystane w badaniach:

a. System Med-El z elektrodami standardowymi, których tylko część umieszczano w schodach bębenka (od 18 do $28 \mathrm{~mm}$ ), elektrody krótsze typu Medium i Flex EAS o długości $20 \mathrm{~mm}$, elektrody SoftFlex, które umieszczano od 22 do $28 \mathrm{~mm}$ w schodach bębenka (w przypadku insercji powyżej $25 \mathrm{~mm}$ możemy mówić o głębokiej insercji w PDT) [12].

b. Systemem firmy Cochlear typu CI422/SRA o długości $20 \mathrm{~mm} \mathrm{z}$ możliwością głębszej insercji do $25 \mathrm{~mm}$ [11].

W przypadku leczenia częściowej głuchoty przy pomocy elektrycznego dopełnienie (PDT-EC) stosowano tylko same procesory mowy. W przypadkach pacjentów zakwalifikowanych do stymulacji łączonej elektryczno-akustycznej najpierw stosowano aparaty słuchowe, a następnie system połączony Duet lub Hybryd. Cały proces opieki pooperacyjnej, fittingu oraz metod rehabilitacji jest tematem innych opracowań.

\section{Wyniki}

Wprowadzenie nowej metody kompleksowo pokazującej możliwości akustycznej i elektrycznej stymulacji ucha

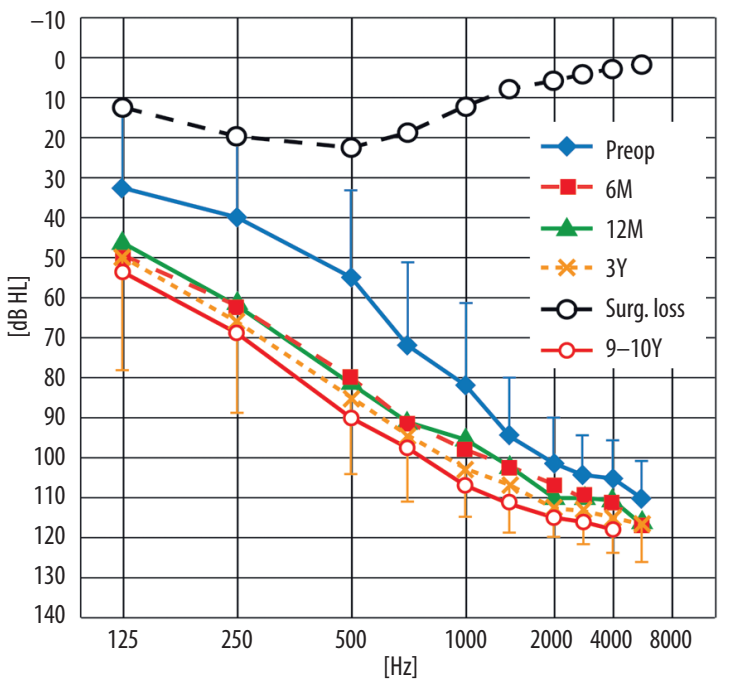

Rycina 8. Zachowanie słuchu przed i po operacyjne w grupie PDT-EAS po 10 latach $(n=43)$

wewnętrznego zdecydowanie rozszerzyło wcześniejsze wskazania do leczenia operacyjnego różnych wad słuchu przy pomocy implantów ślimakowych z elektrodami różnej długości. Najważniejszym i najtrudniejszym zadaniem było wdrożenie po raz pierwszy w 2002 r. programu elektrycznego dopełnienia dobrego słuchu na niskich częstotliwościach i zachowania normalnego słuchu na innych częstotliwościach (PDT-EC) [6]. Na Rycinie 7 przedstawiono przedoperacyjny słuch oraz jego zachowanie w grupie pierwszych 31 osób. Dane te gromadzone były przez 10 lat.

Na uwagę zasługuje bardzo dobre długie zachowanie przedoperacyjnego słuchu na poziomie bardzo niskich częstotliwości oraz resztkowego słuchu na wysokich częstotliwościach. Największe przesunięcie progu zanotowano na poziomie $1000 \mathrm{~Hz}$ w pierwszych 6 miesiącach po operacji. Wczesna pooperacyjna ocena wykazała, że tymczasowo, przez około 2 miesiące, słuch był obniżony o ok. 10-15 dB na wszystkich częstotliwościach. Przesunięcie progu w ciągu następnych 3-6 miesięcy było małe, dlatego stabilny próg uzyskany w ciągu pierwszych 6 miesięcy, wzięto jako stan wyjściowy do długoterminowej obserwacji (10 lat). W okresie 12 miesięcy po operacji (w ramach 10-letniego okresu) nie zaobserwowano żadnego pogorszenia słuchu na znaczącym poziomie niskich częstotliwości w pierwszej grupie pacjentów, u których zastosowano elektryczne dopełnienie (31 osób). Należy tu podkreślić, że przez pierwsze dwa lata do leczenia operacyjnego w grupie PDT-EC kwalifikowano tylko osoby dorosłe, u których w ciągu ok 10 lat wcześniej nie obserwowano pogarszania się słuchu. Można zatem stwierdzić, że słuch u pacjentów z pierwszej grupy został oceniony nie tylko przed operacją, ale zweryfikowany został jego stan w długim okresie przedoperacyjnym.

Na Rycinie 8 przedstawiono analogicznie wyniki pierwszej grupy 43 pacjentów z łączoną stymulacją akustyczną i elektryczną - PDT-EAS na przestrzeniu ponad 10 lat. 


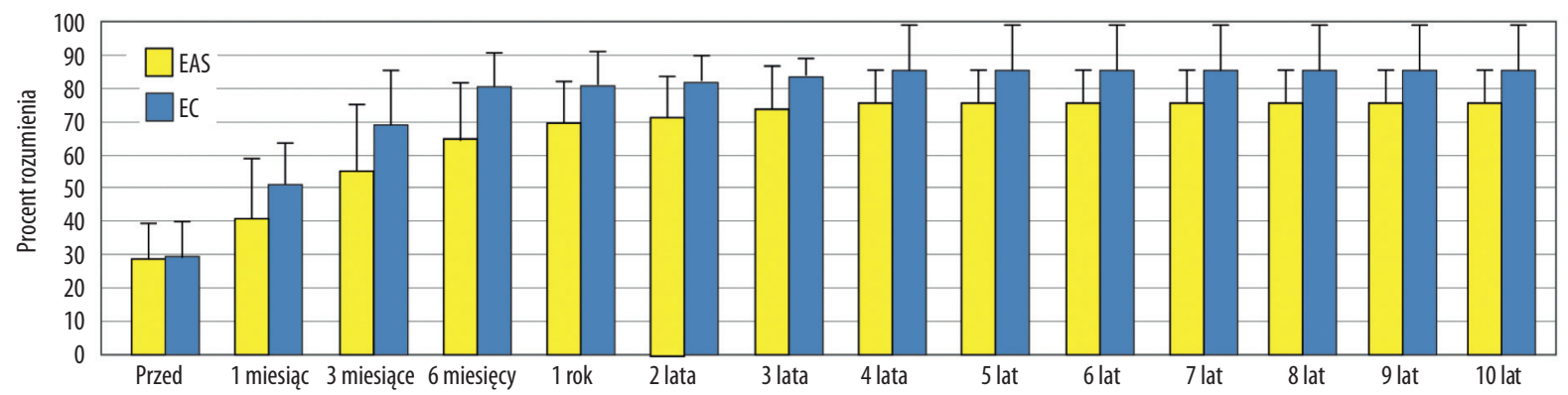

Rycina 9. Poziom rozumienia mowy w ciszy - monosylabowy test słowny. Wyniki grup PDT-EC (niebieski) i PDT-EAS (żółty)

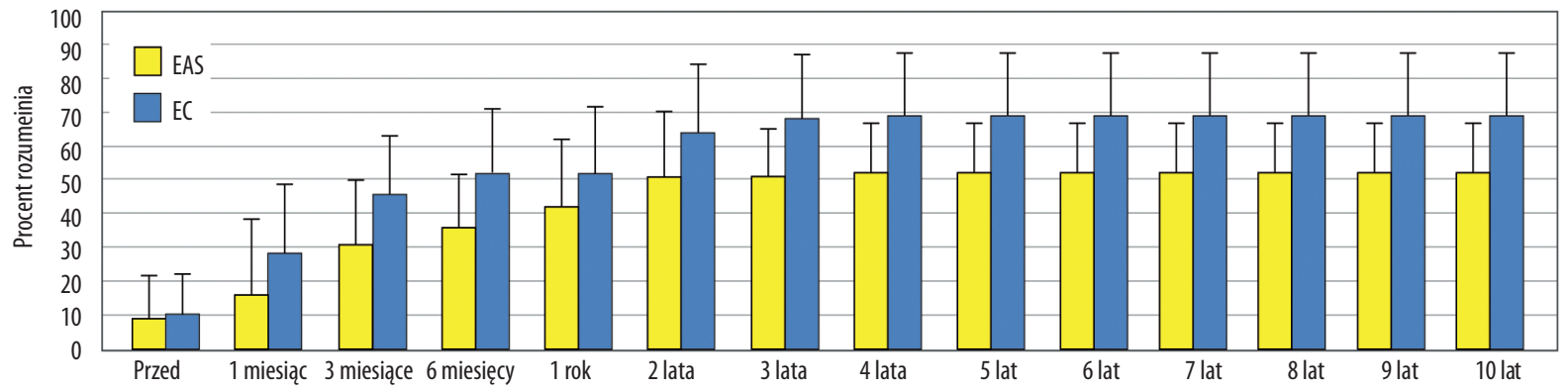

Rycina 10. Poziom rozumienia mowy w hałasie - monosylabowy test słowny. Wyniki grup PDT-EC (niebieski) i PDT-EAS (żółty)

Należy wspomnieć o pogorszeniu słuchu w ciągu pierwszych 6 miesięcy, od 10 do $25 \mathrm{~dB}$ na niskich, najistotniejszych częstotliwościach i stabilnych wynikach na wysokich częstotliwościach. W dalszym okresie obserwacji słuch na przestrzeni kolejnych 9 lat nie ulegal pogorszeniu. Istotne różnice $\mathrm{w}$ trwałym pogorszeniu słuchu w ciągu pierwszych miesięcy i ich praktycznie sporadycznym występowaniu w ciągu dalszych lat nie są łatwe do wytłumaczenia. Sytuację tę może w jakimś stopniu tłumaczyć fakt, że w drugim, nieoperowanym uchu u ok 32,5\% pacjentów obserwowano w różnym stopniu pogarszanie się słuchu. $Z$ obserwacji wynika również, że u 53,4\% przypadków słuch pogarszał się $\mathrm{w}$ niewielkim stopniu w obu uszach na przestrzeni 10 lat przed wykonaniem zabiegu operacyjnego.

Można zatem stwierdzić, że w tych uszach dochodziło do stopniowego pogarszania się słuchu zarówno przed jak i po operacji. Wyjaśnienie tego zjawiska będzie zapewne możliwe po zebraniu i ocenie wyników z dłuższego okresu większej grupy zoperowanych pacjentów, co będzie tematem odrębnej złożonej analizy.

Kolejnym istotnym aspektem związanym z oceną wyników pacjentów są badania rozumienia mowy. Na Rycinach 9 i 10 zostały zaprezentowane wyniki rozumienia mowy. W długim okresiei przy zachowaniu regularnej rehabilitacji, wyniki charakteryzują się dużą stabilnością. Poziom rozumienia mowy, zarówno w hałasie, jak i w ciszy jest wyższy w grupie pacjentów PDT-EC.

Podsumowując należy podkreślić, że przedstawiając kompleksową koncepcję leczenia częściowej głuchoty z różnym przedoperacyjnym słuchem, autorzy zdołali pokazać w kolejnych doniesieniach rozwój tej metody $[8,10,11,13,15]$.
W niniejszym artykule zaprezentowano badania przeprowadzone pomiędzy 2002 a 2012 rokiem u pierwszej grupy 74 osób z PDT, prezentujące metodę leczenia pozwalającą na zachowanie słuchu. Potwierdziło to słuszność przyjętej zarówno klasyfikacji jak i strategii chirurgicznej. W literaturze światowej można odnaleźć opracowania odnoszące się do techniki chirurgicznej jak PDT oraz zastosowania analogicznych kryteriów doboru pacjentów [13,14,16).

\section{Wnioski}

1. Długi okres obserwacji coraz większej grupy pacjentów w różnym wieku wykazał potrzebę stałego rozszerzania wskazań do zastosowania implantów ślimakowych u osób ze znaczącymi resztkami słuchowymi oraz normalnym słuchem przedoperacyjnym na niskich częstotliwościach.

2. Niezmienność wyników oraz bardzo dobre efekty w zachowaniu słuchu potwierdziły optymalny wybór strategii chirurgicznej z wykorzystaniem dojścia do ucha wewnętrznego przez okienko okrągłe.

3. Wyniki obserwacji klinicznych przyspieszyły rozwój nowych elektrod implantów ślimakowych w różnych systemach, co ma ogromne znaczenie nie tylko w zachowaniu przedoperacyjnego słuchu ale również w zachowaniu przedoperacyjnej struktury ucha wewnętrznego.

4. Wykazana niezwykle wysoka skuteczność zachowania przedoperacyjnego słuchu miała znaczący wpływ na:

a. opracowanie nowych strategii wczesnego wykrywania różnych częściowych uszkodzeń słuchu w oparciu o badania przesiewowe;

b. nowych kierunków rozwoju zaplecza i wykorzystania technologii teleinformatycznych. 


\section{Piśmiennictwo:}

1. von Ilberg C., Kiefer J., Tillein J. i wsp.: Electric-acoustic stimulation of the auditory system. New technology for severe hearing loss. ORL J Otorhinolaryngol Relat Spec, 1999; 61: 334-40

2. Gantz B.J., Turner C., Gfeller K.: Expanding cochlear implant technology: Combined electrical and acoustical speech processing. Cochlear Implants Int, 2004; 5(Suppl.1): 8-14

3. Briggs R.J., Tykocinski M., Stidham K., Roberson J.B.: Cochleostomy site: implications for electrode placement and hearing preservation. Acta Otolaryngol, 2005; 125(8): 870-76

4. Skarzynski H., Lorens A., Piotrowska A.: Residual acoustic hearing in the ear before and after cochlear implantation. Presentation at the $5^{\text {th }}$ ESPCI in Antwerp, 2000

5. Skarzynski H., Lorens A., D’Haese P. i wsp.: Preservation of residual hearing in children and post-lingually deafened adults after cochlear implantation: an initial study. ORL J Otorhinolaryngol Relat Spec, 2002; 64(4): 247-53

6. Skarzynski H., Lorens A., Piotrowska A.: A new method of partial deafness treatment. Med Sci Monit, 2003; 9(4): CS20-24

7. Skarzynski H., Lorens A., Piotrowska A., Anderson I.: Partial deafness cochlear implantation in children. Int J Pediatr Otorhinolaryngol, 2007; 71: 1407-13

8. Skarzynski H., Lorens A., Piotrowska A., Skarzynski P.H.: Hearing preservation in partial deafness treatment. Med Sci Monit, 2010; 16(11), CR555-62

9. Skarzynski H., Lorens A.: Partial deafness treatment. Cochlear Implant Int, 2010; 11(Suppl.1): 29-41
10. Skarzynski H., Podskarbi-Fayette R.: A new cochlear implant electrode design for preservation of residual hearing: a temporal bone study. Acta Otolaryngol, 2010; 130: 435-42

11. Skarzynski H., Lorens A., Matusiak M. i wsp.: Partial deafness treatment with the Nucleus Straight Research Array Cochlear Implant, Audiol Neurootol, 2012; 17(2): 82-91

12. Skarzynski H., Lorens A., Zgoda M. i wsp.: Atraumatic round window deep insertion of cochlear electrodes. Acta Otolaryngol, 2011; 131(7): 740-49

13. Prentiss S., Sykes K., Staecker H.: Partial deafness cochlear implantation at the University of Kansas: techniques and outcomes. J Am Acad Audiol, 2010; 21(3): 197-203

14. Dorman M.F., Gifford R.H.: Combining acoustic and electric stimulation in the service of speech recognition. Int J Audiol, 2010; 49(12): 912-19

15. Lorens A., Zgoda M., Obrycka A. i wsp.: Fine Structure Processing improves speech perception as well as objective and subjective benefits in pediatric MED-EL COMBI 40+ users. Int J Pediatr Otorhinolaryngol, 2010; 74(12): 1372-78

16. Helbig S., Baumann U., Hey C., Helbig M.: Hearing preservation after complete cochlear coverage in cochlear implantation with the free-fitting FLEXSOFT electrode carrier. Otol Neurotol, 2011; 32(6): 973-79

17. Gifford R.H., Dorman M.F., Spahr, A.J. i wsp.: Hearing Preservation Surgery: Psychophysical Estimates of Cochlear Damage in Recipients of a short Electrode Array. J Acoust Soc Am, 2008; 124: 2164-73

18. Wilson BS.: Partial deafness cochlear implantation (PDCI) and electric-acoustic stimulation (EAS).Cochlear Implants Int, 2010; 11(Suppl.1): 5-66. Review 